\title{
Studi Awal Implementasi Transduser Piezoelektrik sebagai Piranti Pemanen Energi pada Lantai
}

\author{
Yesiana Arimurti, Y. Radiyono, Surantoro
}

Program Studi Pendidikan Fisika, Universitas Sebelas Maret, Surakarta, Indonesia

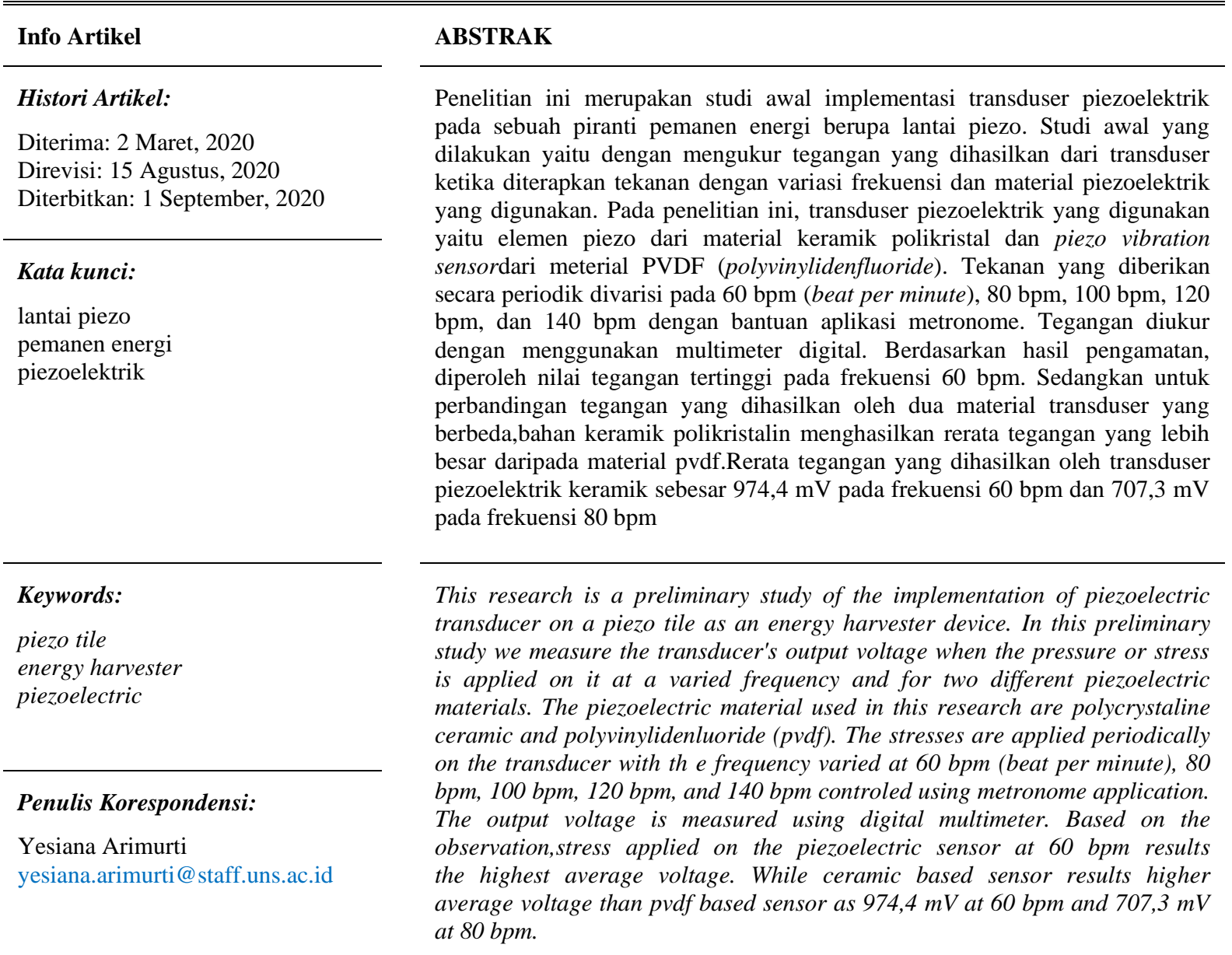

\section{PENDAHULUAN}

Penggunaan piranti elektronik, gawai (gadget), "internet of things", kini semakin marak dan meningkat. Piranti-piranti ini membutuhkan suplai energi nirkabel, terhindar dari kebocoran, dan tidak bergantung pada infrastruktur. Hal ini dapat dipenuhi oleh teknologi pengumpul energy (energy harvesting). Energy harvesting merupakan teknologi untuk mengumpulkan energi listrik, biasanya dalam jumlah kecil, untuk mengoperasikan gawai pribadi (personal gadget) dan piranti-piranti elektronik semacamnya (Laumann, dkk., 2017). Teknologi pengumpul energi telah diterapkan pada 
panel surya fotovoltaik, elemen termoelektrik, sistem fotokimiawi, dinamo putar dan linier, serta piezoelektrik (Gilbert dan Balouchi, 2008).

Energi mekanik bisa ditemui di mana pun di alam ini. Vibrasi di jalan yang berasal dari kendaraan bermotor, aktivitas gerakan manusia, semua itu termasuk energi mekanik yang sering ditemui dalam kehidupan sehari-hari. Vibrasi dari kendaraan bermotor, dapat menyebabkan kerusakan pada struktur jalan, tapi mempunyai potensi untuk dikonversi menjadi energi listrik. Dengan menggunakan karakteristik konversi elektromekanika dari material piezoelektrik, energi getaran dari kendaraan saat melewati jalan dapat dikumpulkan (X. Xu, dkk., 2018).

Pentingnya efisiensi energi kini telah diketahui oleh banyak orang. Kita dapat memperoleh kembali energi yang telah digunakan dengan adanya perkembangan teknologi atau biasa kita sebut sebagai energi terbarukan. Energi yang ditransfer ke tanah oleh manusia saat berjalan dapat diubah menjadi energi listrik. Tujuanini dapat tercapai dengan merancang sebuah sepatu yang dilengkapi dengan bahan piezoelektrik. Variasi beban diterapkan pada bagian sol sepatu yang dilengkapi bahan piezoelektrik (Turkmen dan Celik, 2017). Kecepatan langkah menggunakan sepatu piezoelektrik juga akan mempengaruhi daya keluaran (Qian, dkk., 2018). Pengumpul energi piezoelektrik juga berpotensi untuk mengubah air hujan menjadi tenaga listrik dengan analisis desain transduser yang spesifik agar diperoleh daya yang optimal (Diniardi, dkk., 2017).

Piezoelectric Energy Harvester (PEH) juga telah banyak dikaji untuk diterapkan di trotoar atau jalan raya, dengan mempertimbangkan faktor desain dari jalan dengan transduser piezoelektrik, supaya diperoleh daya yang optimal. Salah satu implementasinya yaitu pada desain polisi tidur piezoelektrik, dengan lindasan kendaraan bermotor sebanyak 60 kali, menghasilkan 2,166 mWh (Yulia, dkk., 2016). Dimensi transduser piezoelektrik juga mempengaruhi daya keluaran. Pada pembebanan 0,7 MPa dan $15 \mathrm{~Hz}$, alat dengan dimensi $150 \mathrm{~mm} \times 150 \mathrm{~mm}$ dengan sembilan transduser paralel diperoleh daya keluaran maksimum sebesar 50,41 $\mathrm{mW}$. Pada pembebanan $0,2 \mathrm{MPa}$ dan $10 \mathrm{~Hz}$, diperoleh daya keluaran maksimum sebesar 2,92 mW (C. Wang, dkk., 2018). Keuntungan menggunakan generator piezoelektrik juga telah dikaji dan diterapkan di jalan Attiki Odos, Yunani. Daerah yang dipilih sebagai tempat penelitian merupakan area urban dengan lalu lintas sehari-hari yang padat. Beberapa faktor penting yang harus diperhatikan dalam proses penerapan teknologi pengumpul energi berbasis piezoelektrik pada jalan, antara lain: (1) panjang jalan yang akan diimplementasikan teknologi ini, (2) jumlah kendaraan per jam yang melewati daerah yang diamati, dan (3) energi listrik dalam $\mathrm{kWh}$ yang dapat dihasilkan dengan mengimplementasikan sistem pengumpul energi berbasis piezoelektrik pada daerah yang diamati (Kokkinopoulos, dkk., 2014). Berdasarkan berbagai penelitian dan inovasi yang telah dilakukan sebelumnya, penerapan teknologi pengumpul energi dengan transduser piezoelektrik di jalan atau trotoar, memberikan hasil yang menjanjikan untuk menyalakan lampu rambu lalu lintas LED (Papagiannakis, dkk., 2016).

Penelitian ini merupakan pengujian awal dari implementasi transduser piezoelektrik pada sebuah purwarupa lantai piezo yang akan dipijak oleh orang-orang yang melaluinya.Pengujian awal dilakukan dengan memvariasi frekuensi tekanan pada elemen piezoelektrik dan membandingkan tegangan keluaran yang dihasilkan oleh dua material piezoelektrik yang berbeda. Studi awal ini dilakukan untuk menentukan faktor apa saja yang mempengaruhi tegangan keluaran dari transduser piezoelektrik sehingga nantinya akan diperoleh desain lantai piezo yang paling efisien, yaitu meliputi bahan transduser apa yang menghasilkan tegangan tertinggi, bagaimana konfigurasinya, berapa jumlah transduser yang diperlukan, bagaimana pengaruh frekuensi pemberian tekanan pada transduser, dan sebagainya. Tujuan akhirnya yaitu untuk memperoleh tegangan keluaran dan arus yang paling besar, sehingga daya yang diperoleh akan maksimal.

\section{METODE}

Skema rangkaian transduser pemanen energi piezoelektrik ditunjukkan oleh Gambar 1. Tegangan yang dihasilkan oleh elemen piezoelektrik masih berupa tegangan AC sehingga perlu dipasang dioda sebagai penyearah. Transduser yang digunakan yaitu elemen piezo sistem PZT dengan bahan polikristalin (keramik) dan piezo vibration sensor dengan bahan polyvinylidenfluoride (PVDF). 


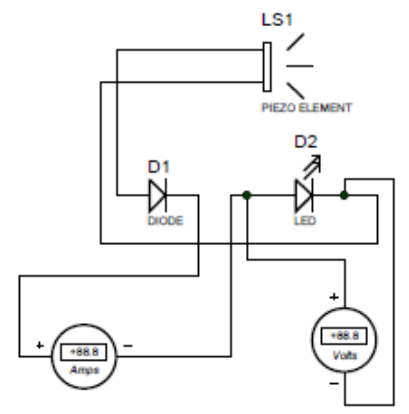

Gambar 1. Skema rangkaian transduser piezoelektrik

Pada Gambar 1, lampu led digunakan sebagai indikator adanya tegangan listrik yang dihasilkan dari tekanan terhadap transduser piezoelektrik. Tegangan dan arus listrik diukur dengan menggunakan multimeter digital pada setiap pemberian tekanan. Pengulangan pengukuran dilakukan tiga kali pada setiap variasi dan diambil nilai reratanya.

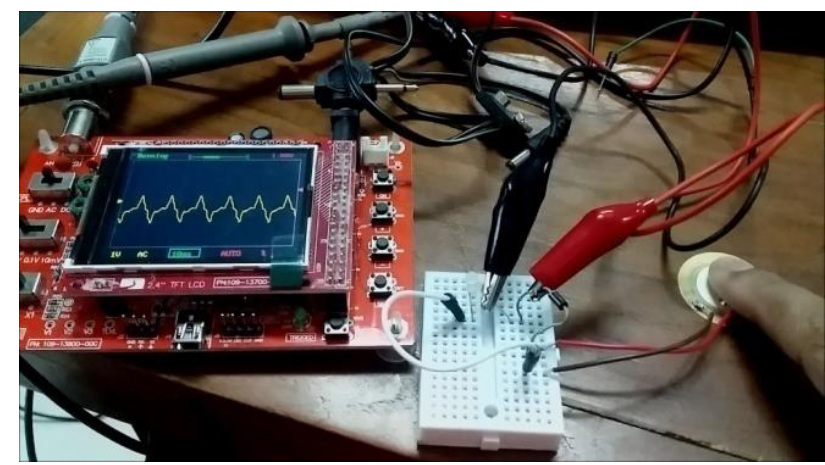

Gambar 2. Uji coba transduser piezoelektrik menggunakan osiloskop digital.

Gambar 2 menunjukkan pengujian elemen piezo bahan keramik polikristalin tanpa penyearah arus dengan menggunakan osiloskop digital. Sinyal pada osiloskop menunjukkan adanya kenaikan puncak ke puncak saat transduser diberi tegangan. Hal ini menunjukkan bahwa elemen piezo masih berfungsi dengan baik sehingga dapat digunakan pada langkah penelitian selanjutnya yaitu menerapkan variasi frekuensi tekanan pada transduser.

Variasi yang dilakukan yaitu variasi frekuensi tekanan terhadap transduser piezoelektrik, dilakukan dengan bantuan aplikasi Metronome pada smartphone dengan satuan bpm atau beat per minute, yaitu $60 \mathrm{bpm}, 80 \mathrm{bpm} .100 \mathrm{bpm}, 120 \mathrm{bpm}$, dan $140 \mathrm{bpm}$. Tekanan yang diterapkan pada transduser piezoelektrik ini akan mengikuti ketukan metronome. Misalnya pada variasi frekuensi tekanan 60 beat per minute, akan dilakukan 60 kali ketukan atau pemberian tekanan pada transduser piezoelektrik dalam satu menit. Pada variasi $80 \mathrm{bpm}$ berarti pemberian tekanan akan dilakukan sebanyak 80 ketukan (beat) dalam satu menit dan seterusnya.
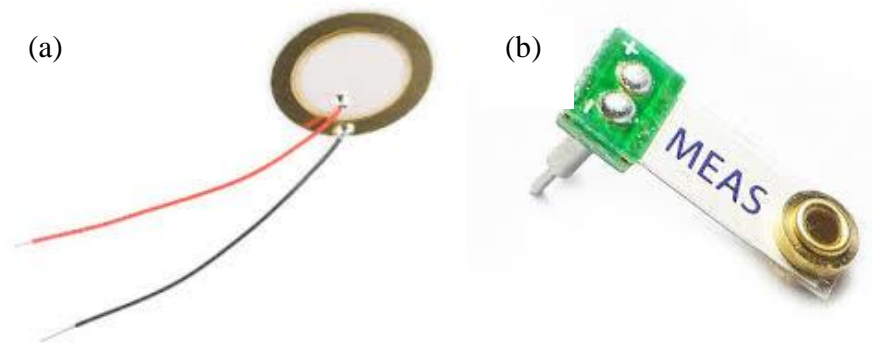

Gambar 3. Variasi bahan sensor piezoelektrik yang digunakan (a) keramik (b) polyvinylidenfluoride 
Selanjutnya, variasi yang dilakukan yaitu penggunaan dua bahan transduser yang berbeda. Pengujian dilakukan dengan transduser elemen piezo berbahan keramik polikristalin dan polimer polyvinylidenfluoride (PVDF) sebagaimana ditunjukkan oleh Gambar 3. Pemberian frekuensi tekanan $60 \mathrm{bpm}$ dan $80 \mathrm{bpm}$ dilakukan masing -masing selama 30 detik.

\section{HASIL DAN DISKUSI}

\subsection{Variasi Frekuensi Tekanan pada Transduser Piezoelektrik}

Hasil pengukuran tegangan pada kaki-kaki lampu LED saat transduser piezoelektrik diberi tekanan dengan variasi frekuensi sebesar $60 \mathrm{bpm}, 80 \mathrm{bpm}, 100 \mathrm{bpm}, 120 \mathrm{bpm}$, dan $140 \mathrm{bpm}$, ditunjukkan oleh Gambar 4. Pengamatan dilakukan dalam selang waktu yang dikontrol yaitu 30 detik. Sehingga, pada variasi 60 bpm terdapat 30 titik data, pada variasi 80 bpm terdapat sekitar 40 titik data, variasi $100 \mathrm{bpm}$ terdapat 50 titik data, $120 \mathrm{bpm}$ terdapat 60 titik data dan pada variasi $140 \mathrm{bpm}$ terdapat 70 titik data.

(a)

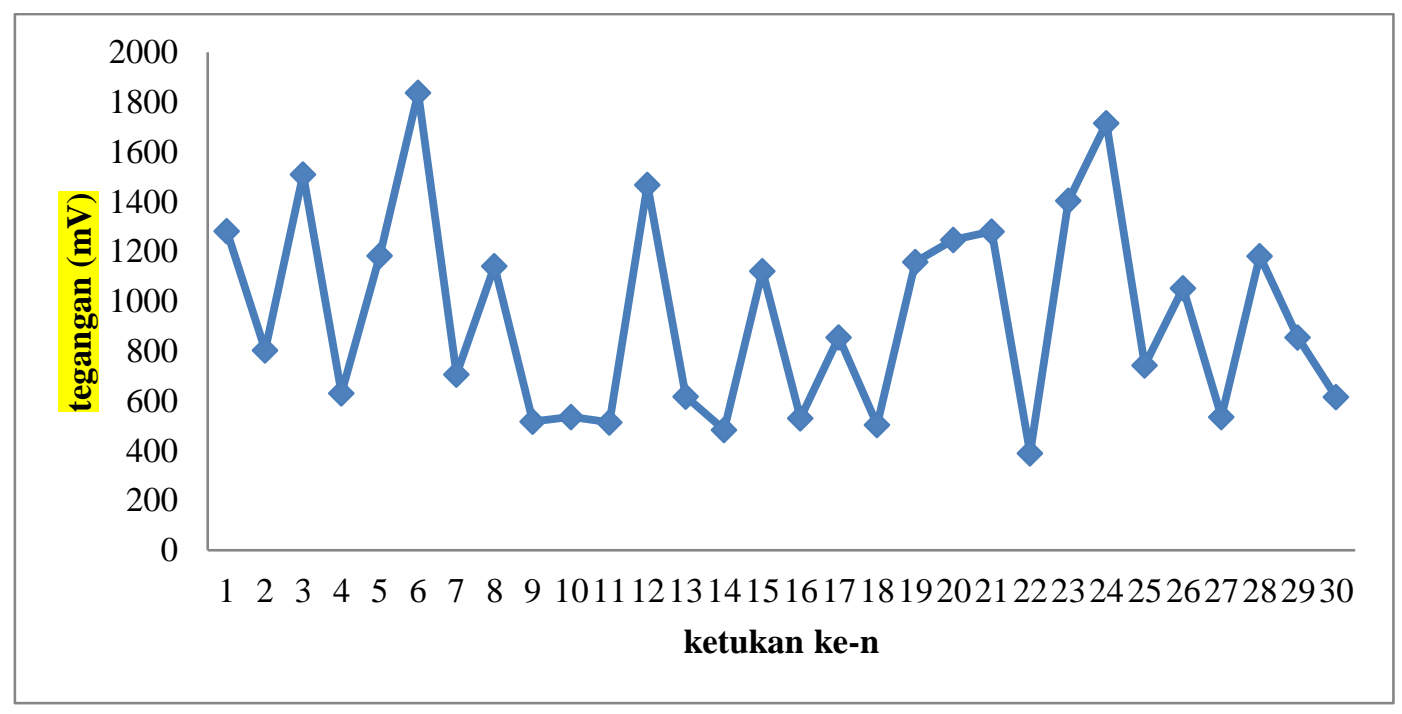

(b)

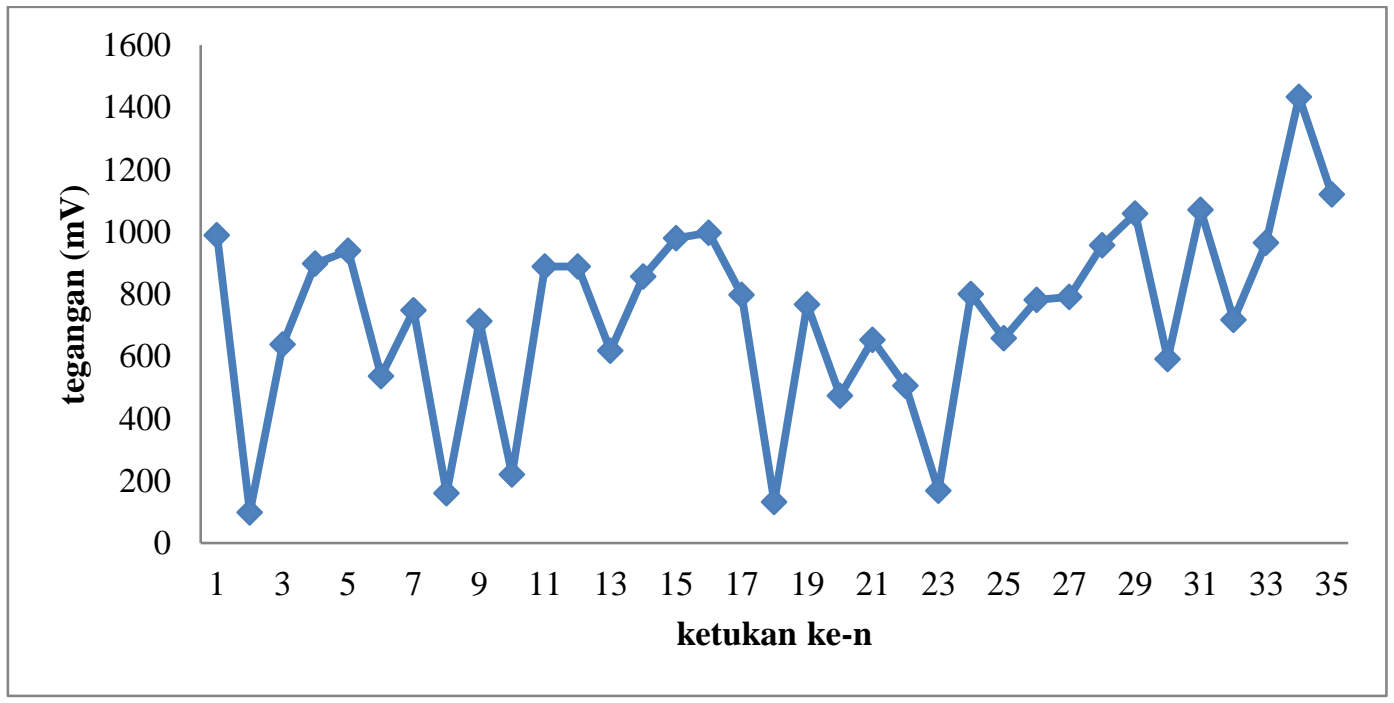


(c)

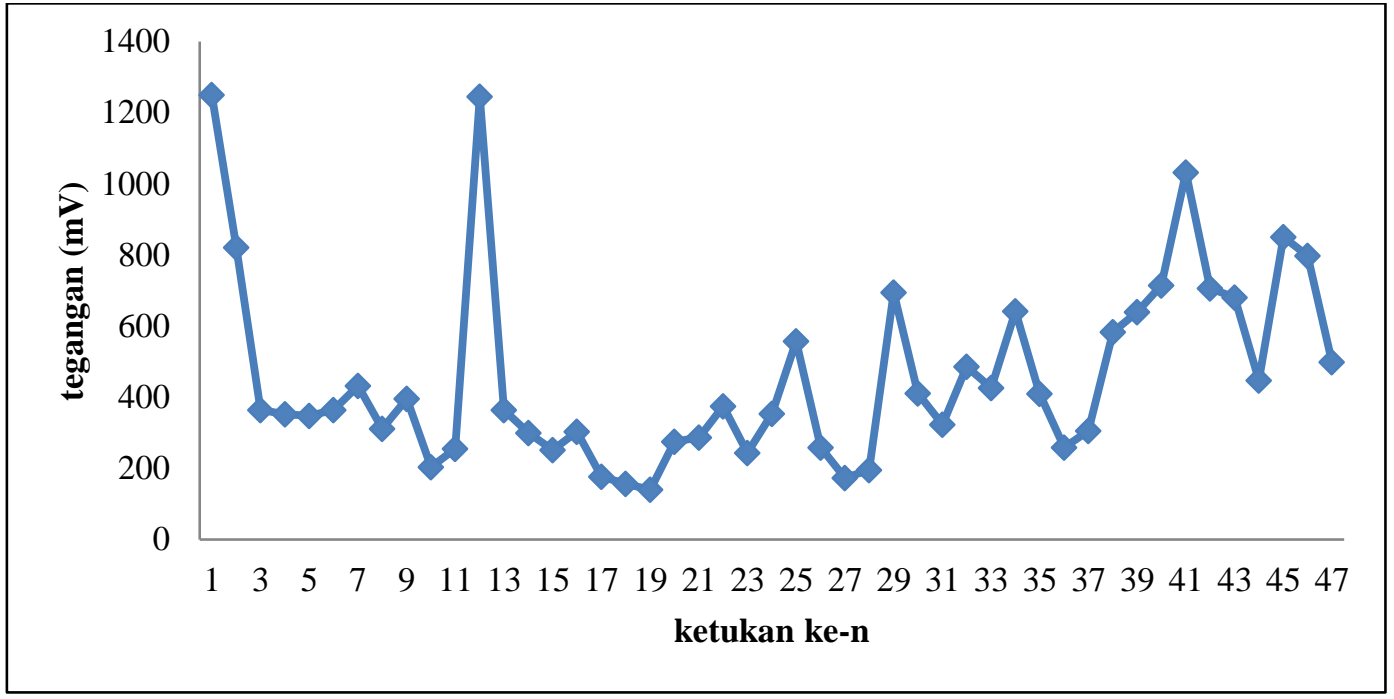

(d)

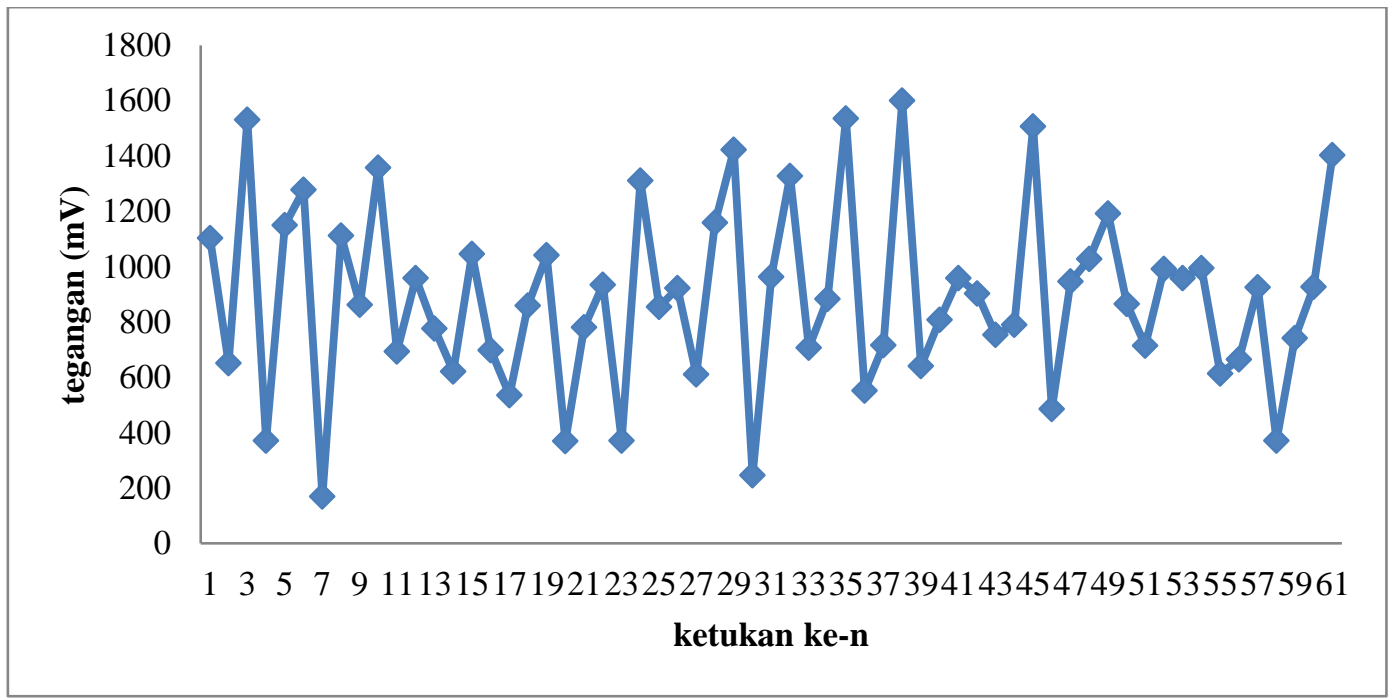

(e)

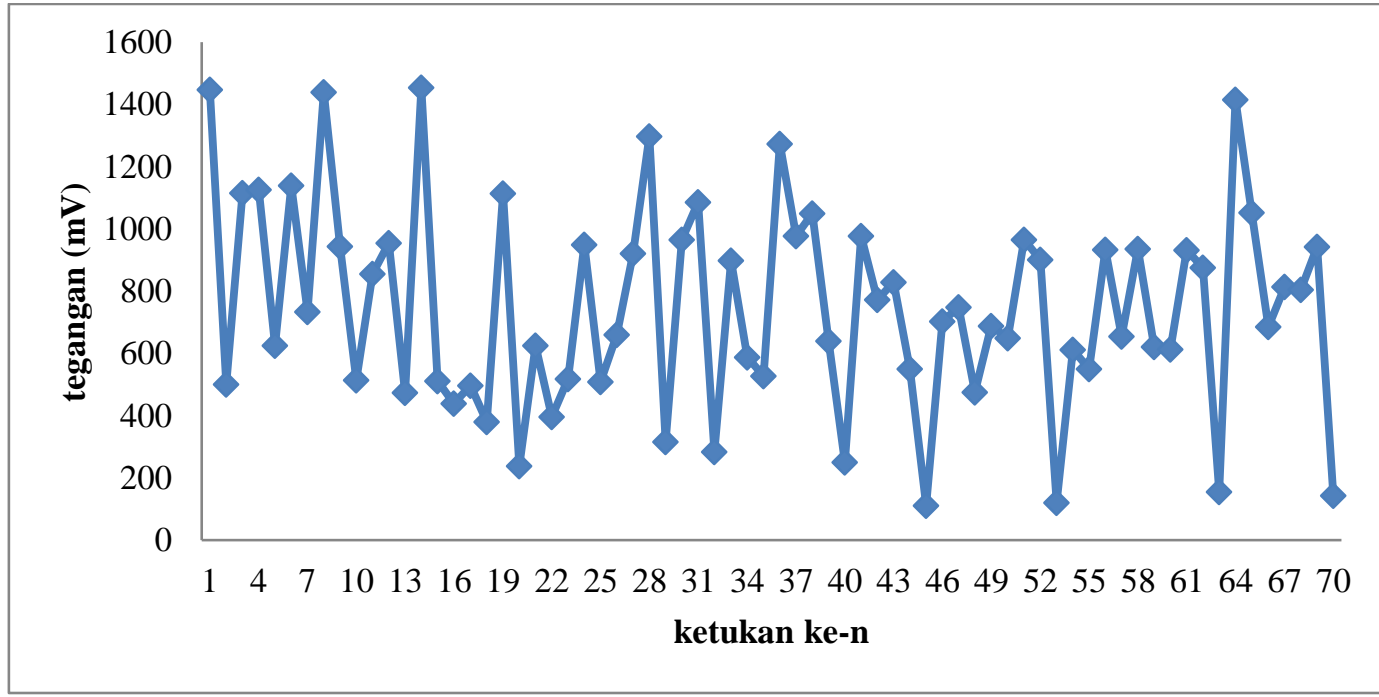

Gambar 4. Hasil pengukuran rerata tegangan keluaran dari transduser piezoelektrik dengan frekuensi tekanan (a) $60 \mathrm{bpm}$; (b) $80 \mathrm{bpm}$; (c)100 bpm; (d) $120 \mathrm{bpm}$; (e) $140 \mathrm{bpm}$ 
Pengukuran tegangan pada setiap kali ketukan atau pemberian tekanan diulang sebanyak tiga kali dan kemudian diambil nilai reratanya. Tabel 1 menunjukkan rerata tegangan yang terukur pada setiap variasi frekuensi tekanan.

Tabel 1. Rerata tegangan terukur pada setiap variasi frekuensi

\begin{tabular}{ccc}
\hline No & Variasi frekuensi $(\mathrm{bpm})$ & Rerata tegangan $(\mathrm{mV})$ \\
\hline 1 & 60 & 947,4 \\
2 & 80 & 707,3 \\
3 & 100 & 477,8 \\
4 & 120 & 881,2 \\
5 & 140 & 749,4 \\
\hline
\end{tabular}

Berdasarkan Gambar 4 dan Tabel 1, dapat diamati bahwa rerata tegangan yang dihasilkan oleh transduser piezoelektrik dengan variasi frekuensi tekanan maksimum sebesar 947,4 mV, pada frekuensi $60 \mathrm{bpm}$. Naik turunnya nilai tegangan yang ditunjukkan oleh Gambar 4 disebabkan oleh desain eksperimen yang memberikan simulasi riil dari penggunaan pemanen energi piezoelektrik berupa lantai piezo, yaitu dengan menginjak atau melompat-lompat diatas transduser. Tekanan yang diberikan pun bergantian sehingga nilai tegangan terukur naik turun. Tegangan terukur saat ada tekanan pada transduser. Sedangkan saat tekanan dilepas, tegangan akan kembali turun. Hal ini sesuai dengan teori sifat bahan piezoelektrik bahwa saat bahan piezoelektrik diberikan tekanan, akan terjadi polarisasi muatan di dalam bahan, sehingga timbul beda potensial. Jika tekanan dihilangkan, muatan dalam bahan piezoelektrik akan kembali random atau acak, sehingga tidak ada beda potensial (Kittel. 2005). Arus yang terukur cenderung konstan untuk semua variasi dengan nilai 3,3 $\mu \mathrm{A}$. Nilai arus ini masih sangat kecil. Daya sesaat (instant power) yang paling tinggi diperoleh berdasarkan rerata tegangan yang paling tinggi yaitu pada variasi frekuensi $60 \mathrm{bpm}$ sebesar $3,1264 \times 10^{-3} \mathrm{~mW}$.

Hubungan antara frekuensi tekanan dan tegangan terukur tidak menunjukkan hubungan yang linier. Hal ini secara spesifik ditunjukkan oleh Tabel 1. Frekuensi tekanan tidak mempengaruhi besar tegangan yang dihasilkan, melainkan mempengaruhi frekuensi energi yang dikumpulkan. Jika energi yang terkumpul disimpan dalam kapasitor, maka semakin besar frekuensi tekanan memungkinkan kapasitor terisi lebih cepat. Besarnya polarisasi atau adanya beda potensial lebih dipengaruhi oleh besarnya tekanan yang dikenakan pada transduser piezoelektrik. Pada pengujian transduser piezoelektrik dengan variasi frekuensi tekanan ini, besar tekanan diusakan untuk dikontrol dengan tidak menambah beban apapun pada pemukul. Sehingga perbedaan tekanan diusahakan seminimal mungkin. Hal ini sesuai dengan aplikasi pada kondisi riil, bahwa transduser piezoelektrik yang berupa lantai piezo akan dipijak-pijak secara sembarang, tidak mengontrol besar tekanan yang dikenakan kepadanya.

\subsection{Variasi bahan piezoelektrik}

Bahan piezoelektrik yang digunakan pada penelitian ini yaitu keramik polikristalin berupa elemen piezoelektrik atau biasa disebut juga piezo buzzerdan bahan polyvinylidenfluoride berupa sensor vibrasi (piezo vibration sensor). Pengukuran tegangan dilakukan pada frekuensi $60 \mathrm{bpm}$ dan $80 \mathrm{bpm}$ dalam waktu 30 detik. Hasil pengukuran tegangan pada kedua variasi bahan ditunjukkan oleh Gambar 5 dan 6. 
(a)

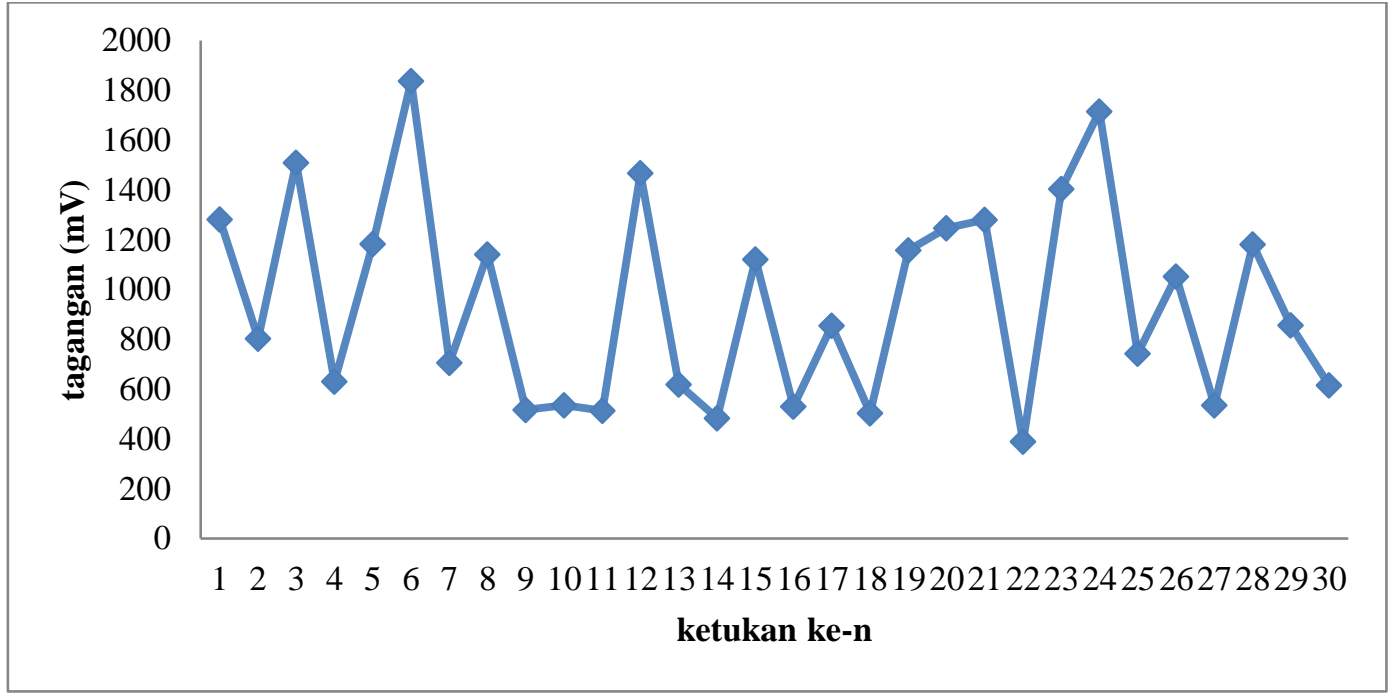

(b)

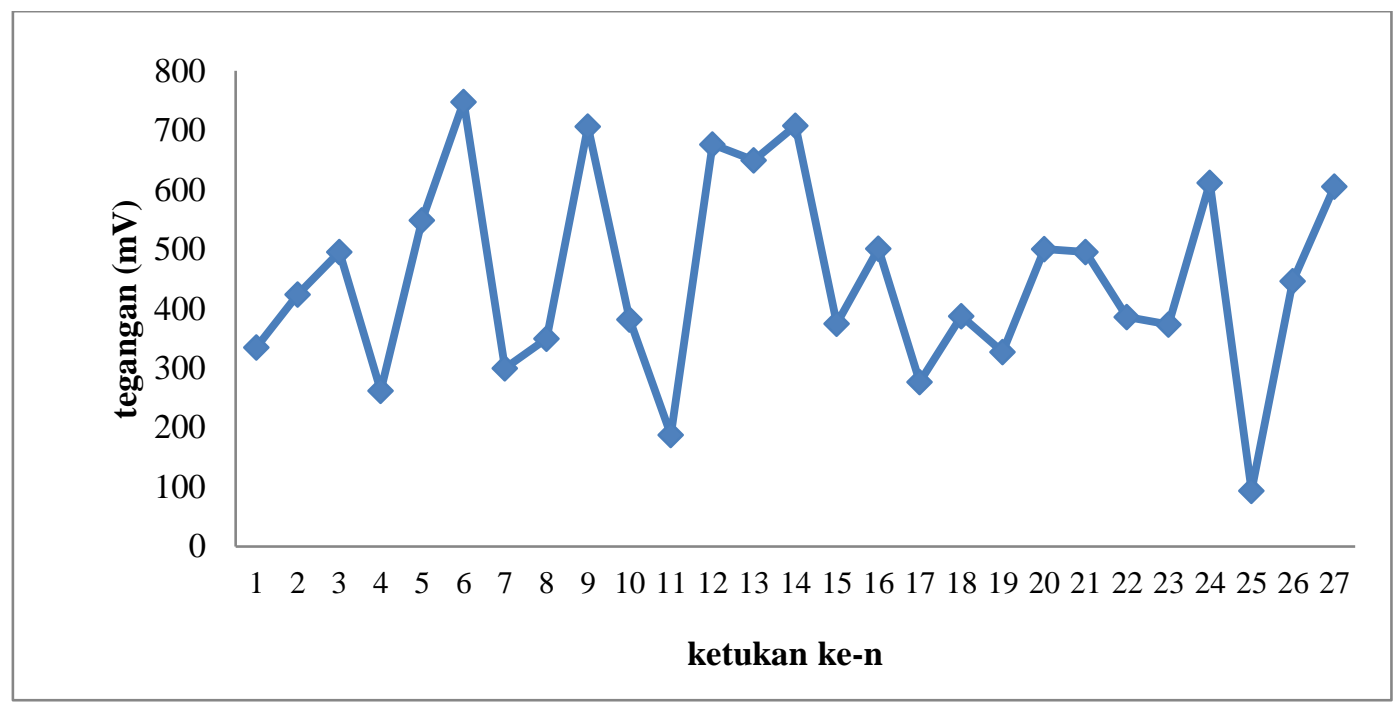

Gambar 5. Tegangan terukur pada transduser piezoelektrik pada frekuensi 60 bpm dengan (a) bahan keramik dan (b) bahan polyvinylidenfluoride

Gambar 5 menunjukkan tegangan terukur pada dua bahan transduser piezoelektrik yang berbeda pada frekuensi pemberian tekanan sebesar $60 \mathrm{bpm}$. Tampak pada Gambar 5a, tegangan yang dihasilkan pada bahan keramik polikristalin terukur lebih tinggi, mencapai sekitar $1800 \mathrm{mV}$. Sedangkan pada transduser piezoelektrik bahan polimer polyvinylidenfluoride yang ditunjukkan oleh Gambar 5b, tegangan tertinggi hanya mencapai sekitar $750 \mathrm{mV}$. 
(a)

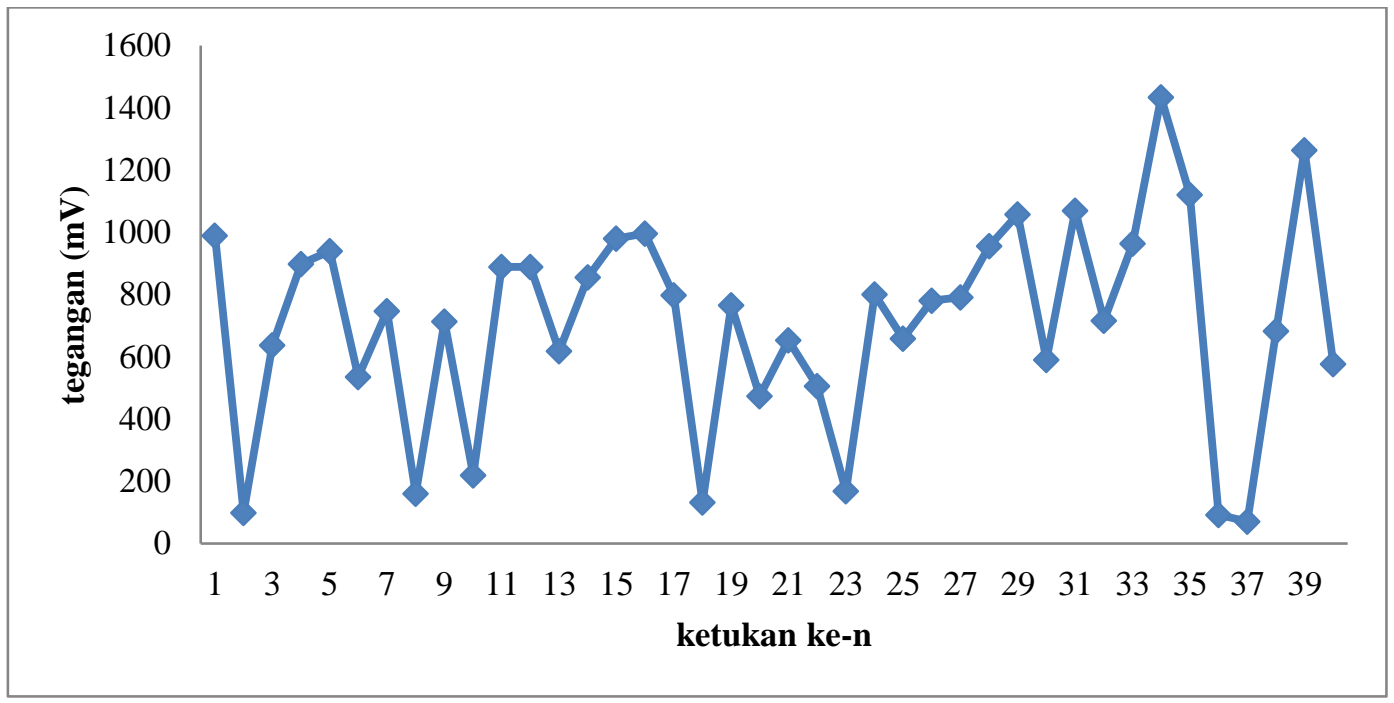

(b)

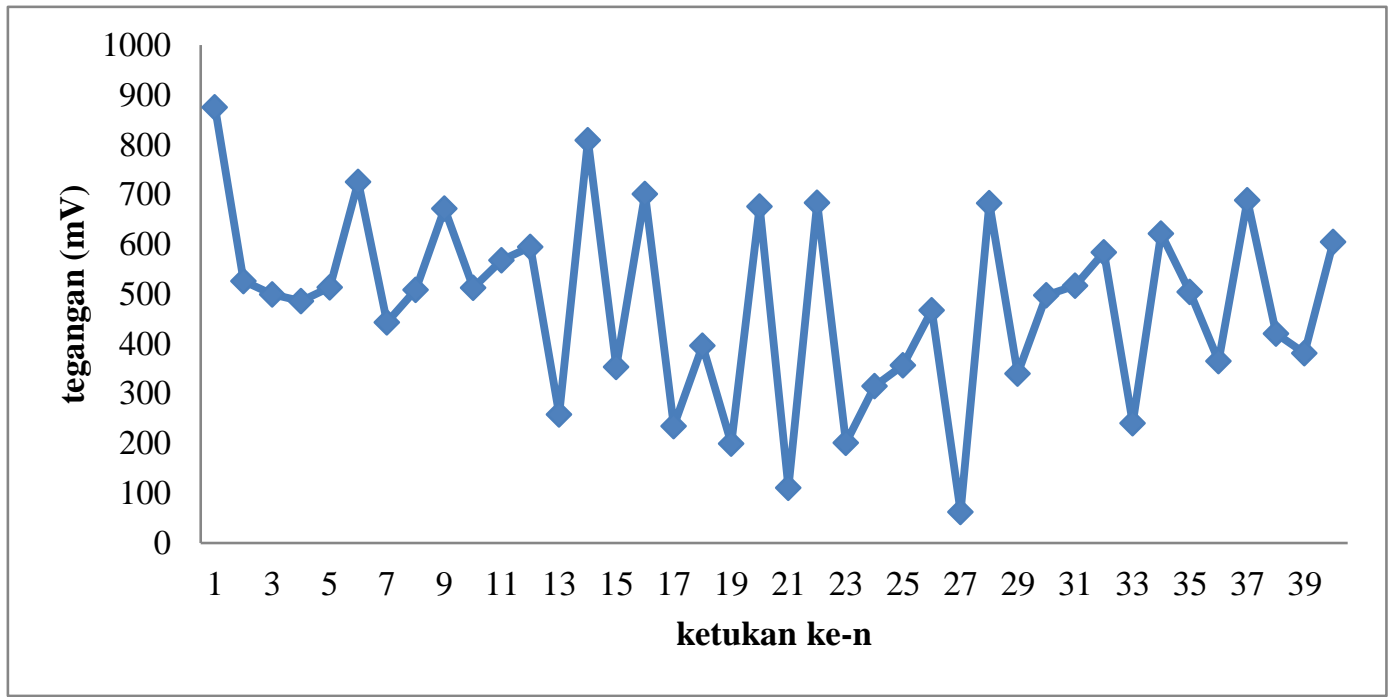

Gambar 6. Tegangan terukur pada transduser piezoelektrik pada frekuensi 80 bpm dengan (a) bahan keramik dan (b) bahan polyvinylidenfluoride

Gambar 6 menunjukkan tegangan terukur pada dua bahan transduser piezoelektrik yang berbeda pada frekuensi pemberian tekanan sebesar $80 \mathrm{bpm}$. Pada Gambar 6a, tegangan yang dihasilkan oleh transduser dengan bahan keramik polikristalin mencapai nilai sekitar $1400 \mathrm{mV}$. Sedangkan pada transduser piezoelektrik bahan polimer polyvinylidenfluoride tegangan tertinggi mencapai sekitar 875 $\mathrm{mV}$, sebagaimanaa ditunjukkan oleh Gambar $6 \mathrm{~b}$.

Tabel 2 menunjukkan rerata tegangan yang diperoleh pada variasi bahan transduser piezoelektrik keramik dan polimer polyvinylidenfluoride dengan frekuensi tekanan yang dibuat tetap yaitu $60 \mathrm{bpm}$ dan $80 \mathrm{bpm}$.

Tabel 2. Rerata tegangan terukur pada variasi bahan piezoelektrik

\begin{tabular}{cccc}
\hline No & $\begin{array}{c}\text { Variasi Frekuensi } \\
(\mathbf{b p m})\end{array}$ & Variasi bahan & Rerata tegangan $(\mathbf{m V})$ \\
\hline 1 & 60 & Keramik & 947,4 \\
2 & \multirow{2}{*}{80} & Polyvinylidenfluoride (Pvdf) & 438,6 \\
\hline 3 & & Keramik & 707,3 \\
4 & & Polyvinylidenfluoride (Pvdf) & 480,0 \\
\hline
\end{tabular}


Secara keseluruhan, berdasarkan Gambar 5 dan 6, serta data pada Tabel 2, dapat diamati bahwa tegangan yang terukur pada bahan keramik lebih tinggi dari pada bahan polimer Polyvinylidenfluoride (Pvdf) baik pada frekuensi tekanan $60 \mathrm{bpm}$ maupun $80 \mathrm{bpm}$. Hal ini berbeda dengan teori yang menyebutkan bahwa polimer sintetis Polyvinylidenfluoride (pvdf) memiliki efek piezoelektrisitas lima kali lebih besar dari pada keramik (Kittel, 2005). Selain itu penelitian yang dilakukan oleh Vatansever, dkk. (2011) juga menyimpulkan bahwa piezoelektrik dengan bahan polimer (pvdf) dapat membangkitkan tegangan dan daya yang lebih tinggi dibandingkan dengan piezoelektrik berbahan keramik. Ketidaksesuaian dengan teori dan hasil penelitian sebelumnya ini bisa jadi disebabkan oleh tekanan yang diberikan kepada kedua jenis bahan piezoelektrik tidak dapat dikontrol dengan baik. Namun demikian, sensor piezoelektrik dengan bahan PVDF memberikan fleksibilitas yang lebih baik. Piezoelektrik berbahan polimer ini lebih tahan lama dan tidak mudah rusak, tidak seperti piezoelektrik keramik. Piezoelektrik berbahan keramik akan mudah rusak atau pecah jika ia mendapat tekanan yang sangat besar. Tidak demikian dengan piezoelektrik polimer (pvdf).

\section{KESIMPULAN}

Faktor utama yang mempengaruhi besarnya tegangan terukur pada transduser piezoelektrik yaitu besarnya tekanan. Semakin besar tegangan atau beda potensial yang terukur, daya yang diperoleh juga semakin maksimal. Frekuensi tekanan tidaklah terlalu berpengaruh signifikan pada kenaikan tegangan selama massa atau tekanan dikontrol tetap sama. Pada frekuensi pemberian tekanan sebesar $60 \mathrm{bpm}$, $80 \mathrm{bpm}, 100 \mathrm{bpm}, 120 \mathrm{bpm}$, dan $140 \mathrm{bpm}$ diperoleh rerata tegangan secara berturut -turut sebesar $947,4 \mathrm{mV} ; 707,3 \mathrm{mV}$; 477,8 mV; 881,2 mV; dan 749,4 mV. Daya sesaat yang optimum pada variasi frekuensi diperoleh nilai sebesar $3,1264 \times 10^{-3} \mathrm{~mW}$. Padavariasi bahan piezoelektrik, bahan keramik polikristalin menghasilkan rerata tegangan keluaran yang lebih tinggi yaitu sekitar $947,4 \mathrm{mV}$ pada frekuensi $60 \mathrm{bpm}$ dan 707,3 $\mathrm{mV}$ pada frekuensi $80 \mathrm{bpm}$, daripada bahan polimer pvdf.

\section{DAFTAR PUSTAKA}

Diniardi, E., Syawaludin, Ramadhan, A. I., Isnaini, W., Dermawan, E., \& Almanda, D. (2017). Analisis Desain Pickup Piezoelektrik Elemen dari Model Hybrid Solar Cell-Piezoelectric. Jurnal Teknologi, 9 (2), 83-88.

Gilbert, J. M., \& Balouchi, F. (2008). Comparison of Energy Harvesting Systems for Wireless Network Sensor. International Journal of Automation and Computing, 05, 334-347.

Kittel, C. (2005). Introduction of Solid State Physics (8 ed.). Danvers, Massachusetts, USA: John Wiley and Sons.

Kokkinopoulos, A., Vokas, G., \& Papageorgas, P. (2014). Energy harvesting implementing embedded piezoelectric generators- The potential for the Attiki Odos traffic grid. Energy Procedia, 50, 1070-1085.

Laumann, F., Sorensen, M. M., Lindemann, R. F., Hansen, T. M., \& Tambo, T. (2017). Energy harvesting through piezoelectricity - technology foresight. Energy Procedia, 142, 3062-3068.

Papagiannakis, A., Dessouky, S., Montoya, A., \& Roshanid, H. (2016). Energy Harvesting from Roadways. Procedia Computer Science, 83, 758-765.

Qian, F., Xu, T.-B., \& Zuo, L. (2018). Design, optimization, modeling and testing of a piezoelectric footwear. Energy Conversion and Management, 171, 1352-1364.

Takefuji, Y. (2008). Known and unknown phenomena of nonlinear behaviors in the power harvesting mat and the transverse wave speaker. Proceedings of Inter-national Symposium on Nonlinear Theory and Its Applikcation. Budapest.

Turkmen, A. C., \& Celik, C. (2018). Energy harvesting with the piezoelectric material integrated shoe. Energy, 556564.

Vatansever, D., Hadimani, R. L., Shah, T., \& Siores, E. (2011). An investigation of energy harvesting from renewable sources with PVDF and PZT. Smart Materials and Structures, 20 (5).

Wang, C., Song, Z., Gao, Z., Yu, G., \& Wang, S. (2019). Preparation and performance research of stacked piezoelectric energy-harvesting units for pavements. Energy \& Buildings, 183, 581-591.

Xu, X., Cao, D., Yang, H., \& He, M. (2018). Application of piezoelectric transducer in energy harvesting in pavement. International Journal of Pavement Research and Technology, 11, 388-395.

Yulia, E., Putra, E. P., Ekawati, E., \& Nugraha. (2016). Polisi Tidur Piezoelektrik Sebagai Pembangkit Listrik dengan Memanfaatkan Energi Mekanik Kendaraan Bermotor. Jurnal Otomasi Kontrol dan Instrumentasi, 8 (1), 105 113. 